\title{
Coastal Geomorphology of a Holocene Hurricane Deposit on a Pleistocene Marine Terrace from Isla Carmen (Baja California Sur, Mexico)
}

\author{
Markes E. Johnson ${ }^{1, *}$, Jorge Ledesma-Vázquez ${ }^{2}$ and Rigoberto Guardado-France ${ }^{2}$ \\ 1 Geosciences Department, Williams College, Williamstown, MA 01267, USA \\ 2 Facultad de Ciencias Marinas, Universidad Autónoma de Baja California, Ensenada 22800, Baja California \\ México; ledesma@uabc.edu.mx (J.L.-V.); rigoberto@uabc.edu.mx (R.G.-F.) \\ * Correspondence: mjohnson@williams.edu; Tel.: +1-413-597-2329
}

Received: 22 August 2018; Accepted: 19 September 2018; Published: 21 September 2018

\begin{abstract}
This study reports the first example of major erosion from hurricanes degrading a rocky coastline anywhere around the Gulf of California, although other sources of evidence are well known regarding the effect of inland erosion due to catastrophic rainfall in the Southern Cape Region of the Baja California peninsula and farther north. The uplifted, 12-m terrace on the eastern shore of Isla del Carmen is the site of an unconsolidated coastal boulder deposit (CBD) consisting of large limestone blocks and boulders eroded from underlying Pliocene strata. The CBD stretches approximately $1.5 \mathrm{~km}$ in length, mostly set back $25 \mathrm{~m}$ from the lip of the terrace. The largest blocks of upturned limestone near the terrace edge are estimated to weigh between 5.8 and 28 metric tons. Waves impacting the rocky coast that peeled back slabs of horizontally-layered limestone at this spot are calculated to have been between 11.5 and $14 \mathrm{~m}$ in height. Analysis of sampled boulders from the CBD set back from the terrace edge by $25 \mathrm{~m}$ suggest that the average wave height responsible for moving those boulders was on the order of $4.3 \mathrm{~m}$. Additional localities with exposed limestone shores, as well as other more common rock types of igneous origin have yet to be surveyed for this phenomenon elsewhere around the Gulf of California.
\end{abstract}

Keywords: hurricane storm surge; hurricane rainfall; hydrodynamic equations; Gulf of California (Mexico)

\section{Introduction}

Atmospheric and marine scientists broadly agree that human-induced climate change is having an impact on the severity and frequency of hurricanes and typhoons on a global scale. The 2017 Atlantic hurricane season ended with four hurricanes above the normal average of six named events, among which Harvey, Irma and Maria were particularly damaging to coastal infrastructure in the USA and Commonwealth of Puerto Rico. A recent analysis by Trenberth et al. [1] shows that the heat content of surface ocean water was the highest on record in the Gulf of Mexico leading to the sustained rainfall event that hit Houston, Texas, 25-28 August 2017 during Hurricane Harvey. Less than a month later, Hurricane Maria devastated Puerto Rico with wind speeds up to $175 \mathrm{~m} / \mathrm{h}(280 \mathrm{~km} / \mathrm{h})$. The final major storm of the 2017 season was Hurricane Ophelia, which reached Ireland on 16 October as a European wind storm packing winds as high as $70 \mathrm{~m} / \mathrm{h}(112 \mathrm{~km} / \mathrm{h})$. It became the easternmost Atlantic hurricane on record.

Similar studies on the 2016 typhoon season in the Pacific basin [2,3] indicate that storm intensity was affected by amplified surface-ocean temperatures and that storm intensification has increased overall by $12-15 \%$ since the late 1970s. In 2016, Typhoon Haiyan became one of the strongest tropical 
cyclones ever recorded, making landfall in the Philippines on 10 November with great loss of life and damage to infrastructure. Hurricanes and typhoons are most prone to immerge over tropical oceans, where the sea-surface temperatures (SSTs) exceed $26^{\circ} \mathrm{C}$. The higher the SST in any given region and the longer it is sustained provide the conditions to spin off major storms. In the recent analysis by Oliver et al. [4], evidence shows that longer lasting and more frequent marine heatwaves have grown globally by $54 \%$ in terms of annual marine heatwave-days since 1925 .

From a geological perspective, certain intervals of pre-historic time are well known from various lines of evidence to have undergone global warming equal to or greater than conditions in place today. The Pliocene Warm Period lasted from about $5-3$ million years ago, during which permanent El Niño conditions strongly affected low latitudes in both the Pacific and Atlantic oceans $[5,6]$. One such region where intense storm-related rainfall can be demonstrated by Pliocene mega-deltas is the peninsular margin of Mexico's Gulf of California [7,8]. It remains to be seen whether or not ongoing climate change will cross a tipping point pushing the planet into a prolonged and possibly irreversible interval of El Niño-like conditions with higher global temperatures, more intense storms and more rainfall comparable to the Pliocene Warm Period.

The storm-related Pliocene sandstone and conglomerate formations of Baja California are massive out-wash deposits from peninsular uplands that reflect the coastal progradation of materials due to excessive rainfall as opposed to the degradation of rocky shorelines under the impact of sea-swell from the same kind of storms. Here, we review the record of hurricane and sub-tropical storm activity within the Gulf of California during the last few decades and focus on an example of rocky-shore erosion attributed to Holocene hurricanes acting on Isla del Carmen, one of the larger fault-block islands with extensive rocky shores in the Gulf of California. The specific aim of this paper is to quantify the wave heights required during major storms to erode the coastline and shift large blocks of limestone inland.

\section{Materials and Methods}

\subsection{Study Area}

The Gulf of California is a marginal sea situated between the Mexican mainland and the Baja California peninsula with a NW-SE axis of $1100 \mathrm{~km}$ long and a 180-km wide opening to the Pacific Ocean at its southern end (Figure 1a). The sea's mean annual SST is $24^{\circ}$, which is higher than the norm of $18^{\circ}$ in the adjacent ocean, and the mean average rainfall on the peninsula amounts to only $15.3 \mathrm{~cm}$ [9]. During relatively infrequent impact by hurricanes, conditions are dramatically altered especially in terms of heavy rainfall over desert terrain lacking thick plant cover. Tropical storms that immerge in the East Pacific Ocean typically form off the coast of Acapulco below $15^{\circ} \mathrm{N}$ latitude and track northward, turning outward to the west before reaching the southern tip of the Baja California peninsula at $23^{\circ} \mathrm{N}$ latitude [10]. Storms that stray across the Baja California peninsula and enter the Gulf of California are called chubascos [11], only some of which amount to hurricane-strength disturbances.

\subsubsection{Greater Gulf of California}

Between 1996 and 2014, five hurricanes came close to or passed directly over Isla Cerralvo (136 km² in area) located east of La Paz in the Lower Gulf of California (Figure 1a, Locality 1). The island is uninhabited, and except for navigational light towers, there is no infrastructure. In a study by Backus et al. [12], it was concluded that as many as 39 prominent fan deltas arrayed around the island's $65-\mathrm{km}$ circumference owed their morphology and maintenance to episodic, but short-lived catastrophic rainfall events lasting hours to days in duration and bringing sand and cobbles through streambeds from the interior to the coast. Passing northward, such disturbances typically deteriorate to tropical storms that still carry a significant amount of precipitation. Among recent hurricanes known to have struck Isla Cerralvo, only one (Fausto, September 1996) deviated eastward on the shortest possible path over the Gulf of California to the Mexican mainland. Hurricanes Marty (September 2003), Ignacio (also 
September 2003), John (August 2006) and Odile (September 2014) followed tracks along the central spine of the Baja California peninsula or along the peninsular gulf coast to dissipate northward in the Upper Gulf of California. Two authors (M.E.J. and J.L.-V.) witnessed the aftermath of Hurricane John in the gulf town of Loreto (Figure 1b), where the northeast corner of the artificial harbor anchored by huge boulders was fully blown out during that storm.
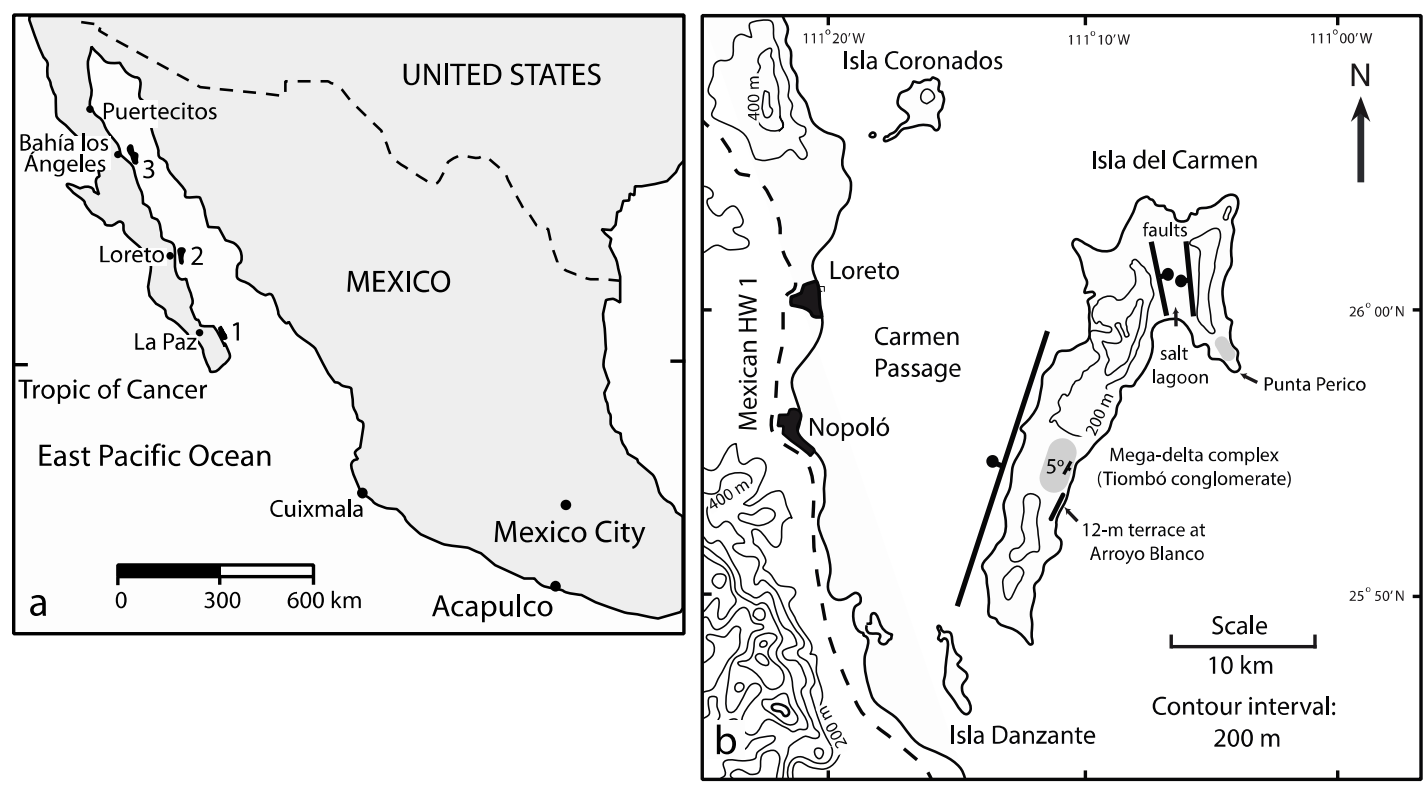

Figure 1. Locality maps showing Mexico's Baja California peninsula and Gulf of California: (a) Mexico, with key cities indicated; (b) Isla del Carmen and local towns on the peninsular mainland.

The effect of sub-tropical storms down-graded from hurricane status in the Upper Gulf of California is apparent from geomorphology and other features related to coastal processes. Near Puertecitos (Figure 1a), the Playa Costilla delta immerges from a normally dry streambed to form a broad delta front with an arc of nearly $5 \mathrm{~km}$, behind which incised distributary channels imply recent activity [13]. Adjacent to the delta, Pliocene Volcán Prieto rises $275 \mathrm{~m}$ above sea level crowned by a crater $350 \mathrm{~m}$ in diameter. The crater is floored by thick clay, apparently derived from erosion of the enclosing crater walls. The last substantial rain events in this highly arid part of the Baja California peninsula were the result of hurricanes Marty and Odile in 2003 and 2014, respectively. Uncharacteristically, Hurricane Kathleen reached all the way to the head of the Gulf of California on 10 September 1976 and continued into southern California in the USA as a Category 2 hurricane [11], packing winds up to $99 \mathrm{mph}(160 \mathrm{~km} / \mathrm{h})$.

During the 2015 season, Hurricane Patricia rapidly formed as a Category 5 hurricane on 23 October with an eye located some $650 \mathrm{~km}$ south of Cabo San Lucas at the tip of the Baja California peninsula. Wind speeds up to $215 \mathrm{mph}(346 \mathrm{~km} / \mathrm{h})$ and a minimum central pressure of $879 \mathrm{mb}$ made it the strongest hurricane on record in the eastern North Pacific and the strongest ever to strike Mexico [14]. Although the storm made landfall on mainland Mexico far south of the Gulf of California, the outermost bands of that storm swept across the opening to the gulf. Significant damage to infrastructure and possible loss of life were averted on the Baja California peninsula by an atypical turn in the path of Hurricane Patricia striking near Cuixmala on the Mexican mainland (Figure 1a) before continuing northward to Texas in the USA as a down-graded subtropical storm.

\subsubsection{Isla del Carmen}

Geographically, the principal focus of this paper relates to Isla del Carmen, the fourth largest in size within the Gulf of California with an area of $143 \mathrm{~km}^{2}$. The island is separated from the peninsular mainland by the 10-15 km-wide Carmen Passage off the towns of Loreto and Nopoló in 
Baja California Sur (Figure 1b) with combined populations exceeding 25,000. Most of the island is dominated by Miocene andesite, but the central part features a thick deposit of Pliocene limestone at Arroyo Blanco on the eastern shore, where a succession of Pleistocene marine terraces is cut into limestone, making distinct steps at $12 \mathrm{~m}, 37 \mathrm{~m}, 58 \mathrm{~m}$ and $68 \mathrm{~m}$ above sea level [15]. Bordering these terraces immediately to the north is the mega-delta complex formed by the Tiombó conglomerate with a thickness of $60 \mathrm{~m}$. The complex is interpreted as a major outwash delta during the Pliocene Warm Period, when the island was still connected to the peninsular mainland [7]. Extending along a lateral distance of $1.5 \mathrm{~km}$, the 12-m terrace forms the geomorphic step on which a chaotic deposit of detached and broken limestone slabs resides. The circumstances under which flat-lying limestone layers were pried loose from the outer edge of the marine terrace as heavy blocks and transported landward by as much as $25 \mathrm{~m}$ are a curiosity of nature that prompted this study. The shoreline trend and the stratigraphic context from which boulders were derived and deposited are readily traceable.

\subsection{Methods}

\subsubsection{Data Collection}

Arroyo Blanco was visited on 13 February 2018, when the original data for this study were collected from that portion of the 12-m terrace directly north of the cove and small beach connected with the drainage from the central arroyo. Extensive photographs were recorded to show variations in Pliocene limestone surfaces exposed along the top of the terrace, as well as various configurations of limestone blocks pealed back from the outer rim of the terrace. Manual measurements were made in three dimensions for examples of the largest slabs tipped vertically on edge, and care was taken to match the bottom faces of such blocks with distinct bedding planes left intact. Additional measurements were collected in three dimensions for a sampling of 25 representative blocks in a chaotic ridgeline set back from the outer lip of the terrace by $25 \mathrm{~m}$.

A typical piece of Pliocene limestone was trimmed from one of the large slabs and brought to a laboratory at Williams College, where it was weighed and its volume was determined as a function of equal displacement when submerged in a large beaker holding $1100 \mathrm{~mL}$ of water. Prior to immersion, the porous limestone sample was water-proofed by spraying it with Thompson's Water Seal ${ }^{\mathrm{TM}}$.

Variations in the shapes of limestone blocks deposited in the ridge line set back from the outer terrace edge were analyzed on the basis of a formula developed by Sneed and Folk [16] for a triangular plot originally used to appraise the morphogenesis of river pebbles.

\subsubsection{Hydraulic Model}

Once the density and weight of measured blocks were calculated based on the limestone sample treated in the laboratory, a hydraulic model was adopted to convey the energy needed to shift blocks of a particular size from the cliff edge and transport them landward across the surface of the marine terrace. Along with shape, size and density, the pre-transport environment of coastal boulders factors into the wave height required them to be moved. Boulders derived from joint-bound blocks on the shore platforms mainly are influenced by lift force, alone, and require much higher waves to initiate transport in comparison to boulders siting in a submerged or subaerial position. To initiate motion of a joint-bound block, the lift force must overcome the force of restraint minus buoyancy, provided the block has loosened completely from its substrate. Herein, the general formula applied to calculate wave height is taken from the work of Nott [17], used for estimation of storm waves.

$$
H_{s} \geq \frac{\left(P_{s}-P_{w} / P_{w}\right)^{2 a}}{C_{d}\left(a c / b^{2}\right)+C_{1}}
$$

where $H_{\mathrm{s}}=$ height of the storm wave at breaking point, $u=(\mathrm{gH})^{0.5}$ and $\partial=1$. 
$a, b, c=$ long, intermediate and short axes of the boulder $(\mathrm{m})$

$P_{\mathrm{s}}=$ density of the boulder (tons $/ \mathrm{m}^{3}$ or $\mathrm{g} / \mathrm{cm}^{3}$ )

$C_{\mathrm{d}}=$ drag coefficient

$C_{\mathrm{m}}=$ coefficient of mass $(=2)$ and $C_{1}=$ lift coefficient $(=0.178)$

$u=$ instantaneous flow acceleration $\left(=1 \mathrm{~m} / \mathrm{s}^{2}\right)$

and $\mathrm{g}=$ gravitational acceleration $\left(=9.81 \mathrm{~m} / \mathrm{s}^{2}\right)$

A variation on this formula applied exclusively to joint-bounded boulders is as follows [17]:

$$
H_{s} \geq\left(P_{s}-P_{w} / P_{w}\right) a / C_{1}
$$

\section{Results}

\subsection{Stratigraphic and Geomorphic Context}

Perspective on the eastern, mid-island rocky shore of Isla del Carmen is provided in Figure 2, which shows lithological facies represented by Pliocene limestone juxtaposed against the Pliocene conglomerate from the Tiombó mega-delta complex. The two facies are equivalent in age and were deposited side-by-side [8]. During Pleistocene time, the entire island underwent tectonic uplift, and marine terraces were eroded step-wise on the older Pliocene limestone. The youngest of these is the 12-m terrace, regionally regarded as dating from the last interglacial episode approximately 125,000 years ago [17]. Whereas the Pliocene limestone is well cemented and forms resistant cliffs, the adjacent conglomerate is poorly aggregated and subject to cliff failure. Contiguous Pleistocene terraces may have developed on the conglomerate, but are no longer present, and that part of the shoreline is recessed in comparison to the adjacent limestone rocky shore. Pleistocene bivalve borings (some retaining shells) are present in places atop the 12-m terrace and attest to a former wave-washed platform.

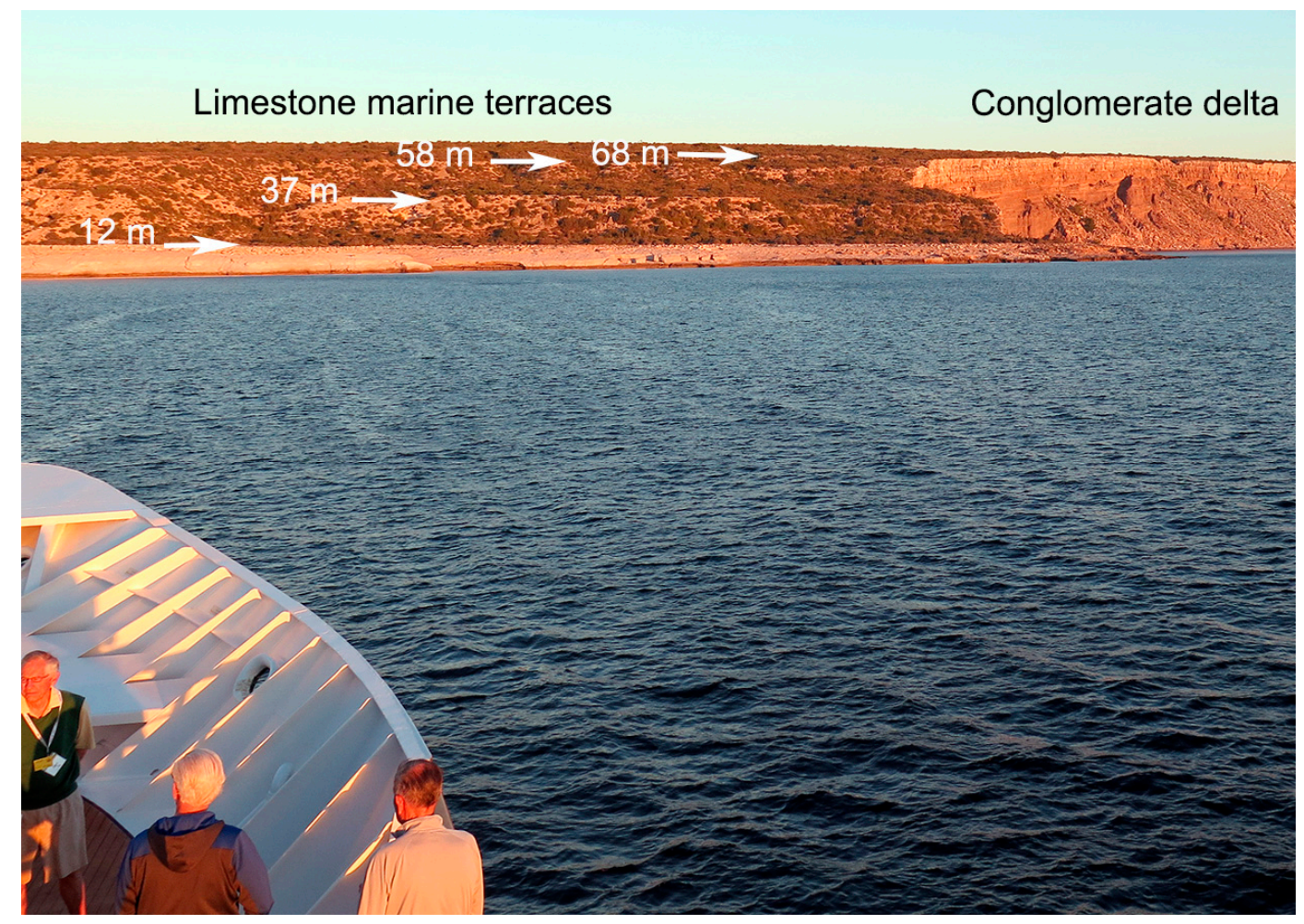

Figure 2. View from the sea showing a stretch of the rocky coast along the east side of Isla del Carmen with adjacent lithologic facies represented by the Pliocene Tiombó mega-delta (right) and Pliocene limestone secondarily eroded with Pleistocene marine terraces at four levels. 
Limestone blocks found loose in chaotic deposits on the 12-m terrace are correlated with particular intervals in the basal $14 \mathrm{~m}$ of the Pliocene Arroyo Blanco Limestone [15]. Most of the basal layers are dominated in content by the lithified debris of crushed rhodoliths, the spherical nodules commonly accreted by coralline red algae. A distinctive one-meter thick interval with fossil bivalve shells including abundant pecten shells is widespread with bedding planes exposed over large parts of the $12-\mathrm{m}$ terrace. Andesite cobbles often are incorporated at the bottom of the shell beds. However, the predominant matrix within these shell beds still consists of abraded rhodolith fragments. All of the disturbed limestone blocks on the 12-m terrace were derived from the fossil shell beds or the immediately underlying fossil rhodolith beds within a roughly 2-m interval.

\subsection{Sample Density Calculation}

The limestone sample retrieved for laboratory analysis is correlated with the shell bed (described above) and has maximum dimensions $12 \mathrm{~cm} \times 10 \mathrm{~cm} \times 5 \mathrm{~cm}$ on three axes perpendicular to one another. However, the size of a rectangular box with these dimensions is not suitable for a simple multiplication in cubic centimeters $\left(600 \mathrm{~cm}^{3}\right)$, due to the sample's irregular shape lacking right angles at each corner. The weight of the sample was found to be $745 \mathrm{gm}$. After treatment to make it water-tight, submergence of the sample in a graduated beaker registered a displacement of water equal to $400 \mathrm{~mL}$. Dividing mass by volume yielded a density of 1.86 for the limestone sample. Checking the laboratory result for volume against the mathematical result, it was found that the actual volume was only $68 \%$ of the former. Roughly the same adjustment regarding irregular shapes is necessary to take into account all three-dimensional measurements collected from mega-boulders in the field.

\subsection{Estimates of Maximum Block Size and Weight}

Overall, the weight of the largest upturned blocks on the marine terrace may be scaled against the calculated volume, density and weight of the laboratory sample. A very large block near the outer lip of the terrace was measured with crude bedding-plane dimensions $4.5 \mathrm{~m}$ by $1.60 \mathrm{~m}$ and a bedding thickness of $0.75 \mathrm{~m}$ (Figure 3). Were the block perfectly rectangular with all right-angle corners, its volume would be $4.5 \mathrm{~m}^{3}$. A conservative estimate of the actual volume taking into account a $30 \%$ reduction from the formula calculation comes to $3.15 \mathrm{~m}^{3}$. Given the density of the limestone sample, the estimated weight of this particular block might be 5.86 metric tons.

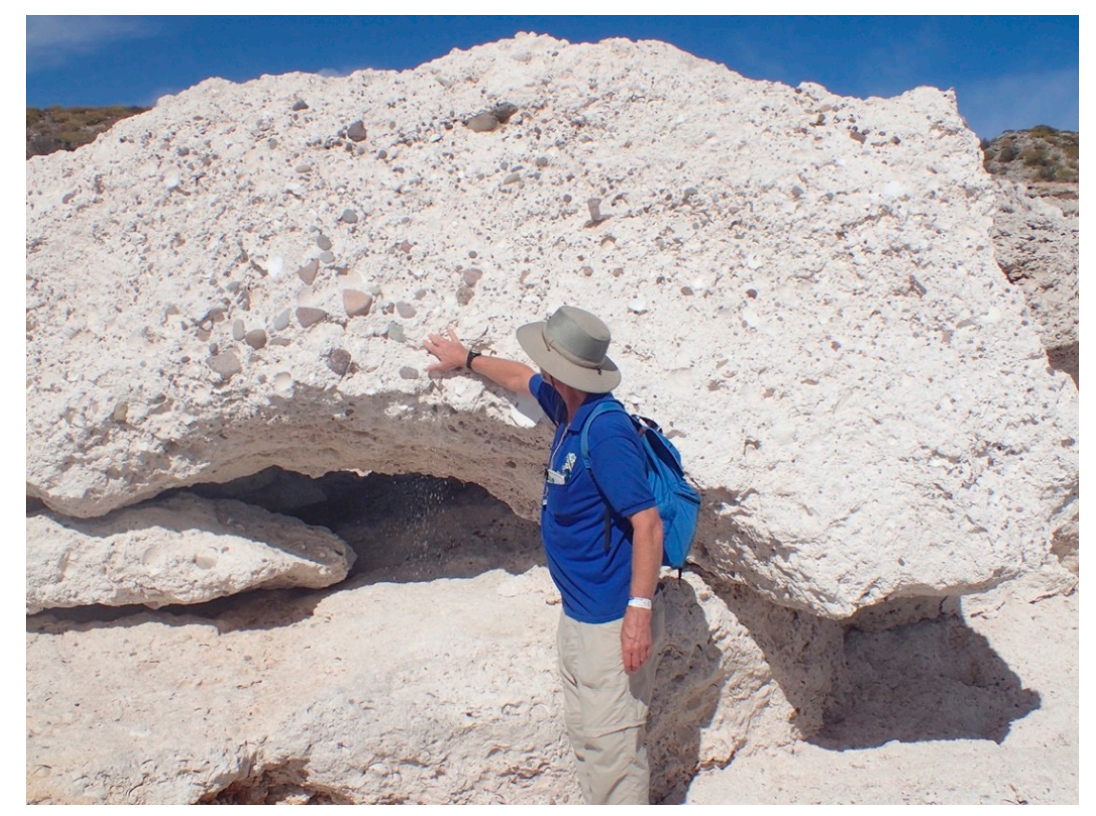

Figure 3. Large block of Pliocene limestone tilted on edge near the rim of the 12-m terrace at Arroyo Blanco, showing a basal layer with andesite cobbles that can be matched to an intact surface, below. 
The largest upturned block identified on the 12-m terrace was measured with crude bedding-plane dimensions $5.4 \mathrm{~m}$ by $4 \mathrm{~m}$ and a bedding thickness of $1 \mathrm{~m}$ (Figure 4). Again, were the block perfectly rectangular, its volume should be $21.6 \mathrm{~m}^{3}$. The conservative estimate based on a $30 \%$ discount for the volume of an irregular shape amounts to a little more than $15 \mathrm{~m}^{3}$. Based on the density of sample limestone, this block could amount to nearly 28 metric tons in weight. In both cases, the seaward-facing surface of the two big blocks (standing normal to the outer edge of the terrace) can be demonstrated to represent the bottom plane of the layers. This inference is based on the inclusion of scattered andesite cobbles that can be matched with cobble-bearing layers still intact on the adjacent terrace surface (Figure 3) or abundant bivalves with a predominantly concave down orientation (stable) (Figure 4). It is notable that the smaller block with matching andesite cobbles is balanced upright with one corner resting on a smaller detached block and another at a level at least a meter above the terrace surface with similar cobbles. In the example of the large block, the match is based on the similar orientation of the same kind of fossil bivalves on the adjacent terrace surface.

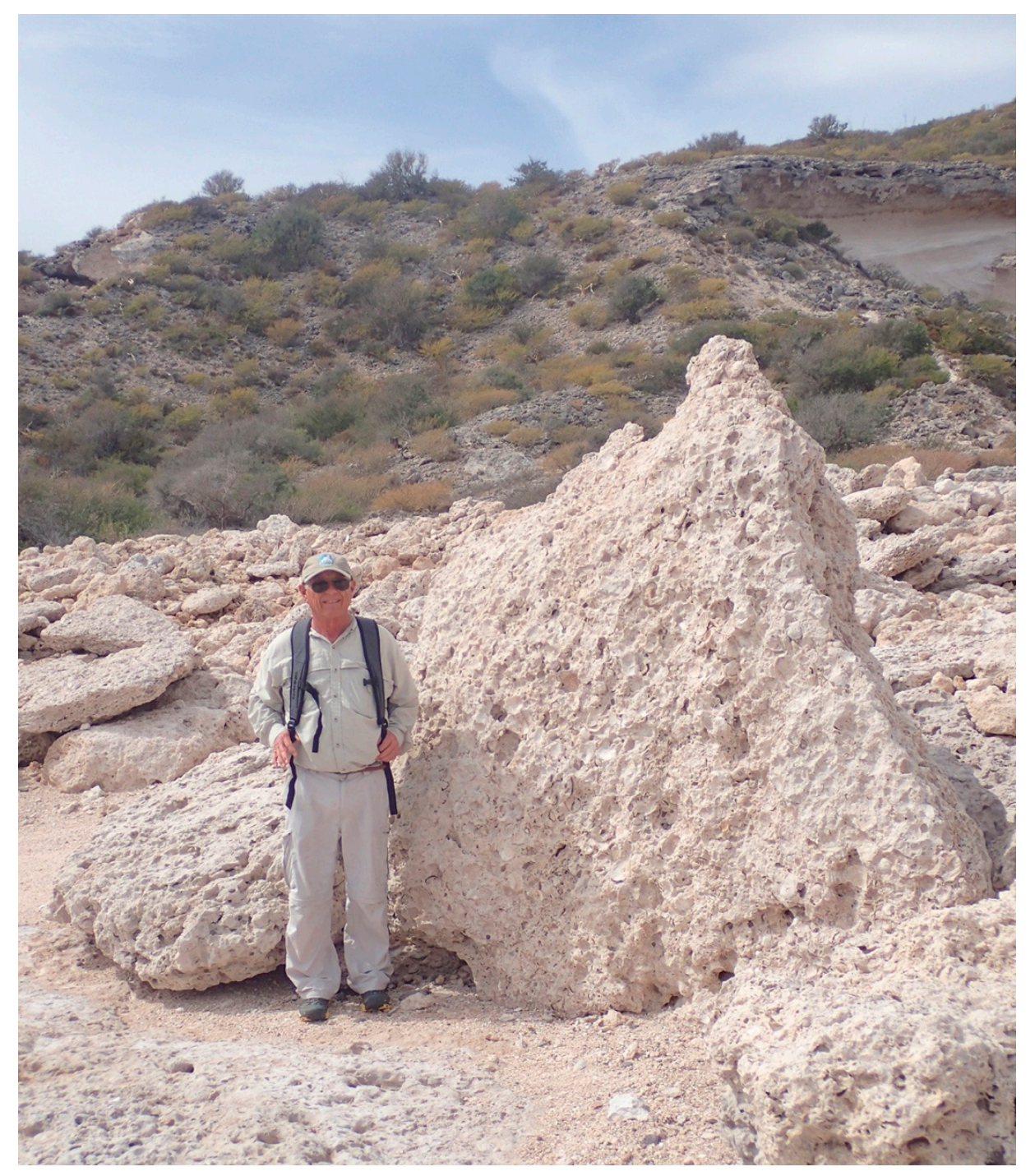

Figure 4. Another, but thicker block of Pliocene limestone that sits tilted on edge further back from the rim of the 12-m terrace at Arroyo Blanco. Extensive fossil bivalves with shells dominantly convex downward match the adjacent surface from which it was peeled away. 


\subsection{Analysis of Shape Variation}

Shown in Figure 5, the coastal boulder deposit (CBD) formed by loose limestone boulders extends parallel to the outer edge of the marine terrace, but set back $25 \mathrm{~m}$ from the seaward front on a scoured limestone surface. Table 1 records the rough dimensions, formula volumes, adjusted volumes and estimated weights from a sample of 25 blocks in the limestone boulder deposit. Estimated weights vary from nearly one metric ton to $27 \mathrm{~kg}$ with an average value of $308 \mathrm{~kg}$ for the full sample. Although it cannot be assumed in every case that the shortest of three dimensions represents an approximation of the original bedding thickness, it is more likely so than not. Generally, the average box shape for the sample is close to a rectangle one meter long by a half meter wide with a depth of $0.33 \mathrm{~m}$. The individual blocks are plotted on a Sneed-Folk triangular diagram (Figure 6) showing the actual variation in shapes. Those points closest to the center of the diagram are most faithful to the average value. The absence of points at the top of the triangle signifies that no equidimensional cubes are present in the sample. Furthermore, the lack of points in the lower, left tier of the triangle shows that squarely plate-shaped blocks are not represented in the assembly. The points trace a general trend in direction from the center to the lower right tier of the diagram that denotes the presence of a subpopulation distinctly bar-shaped in configuration. The significance of the diagram puts heavy emphasis on the thickness of the parent limestone layers and the spacing of intersecting vertical joints in the same parent beds. This has a direct bearing on the relative ease with which individual blocks might be pried loose from the bedrock and tilted upright, or even transported a fair distance landward from the outer margin of the marine terrace.

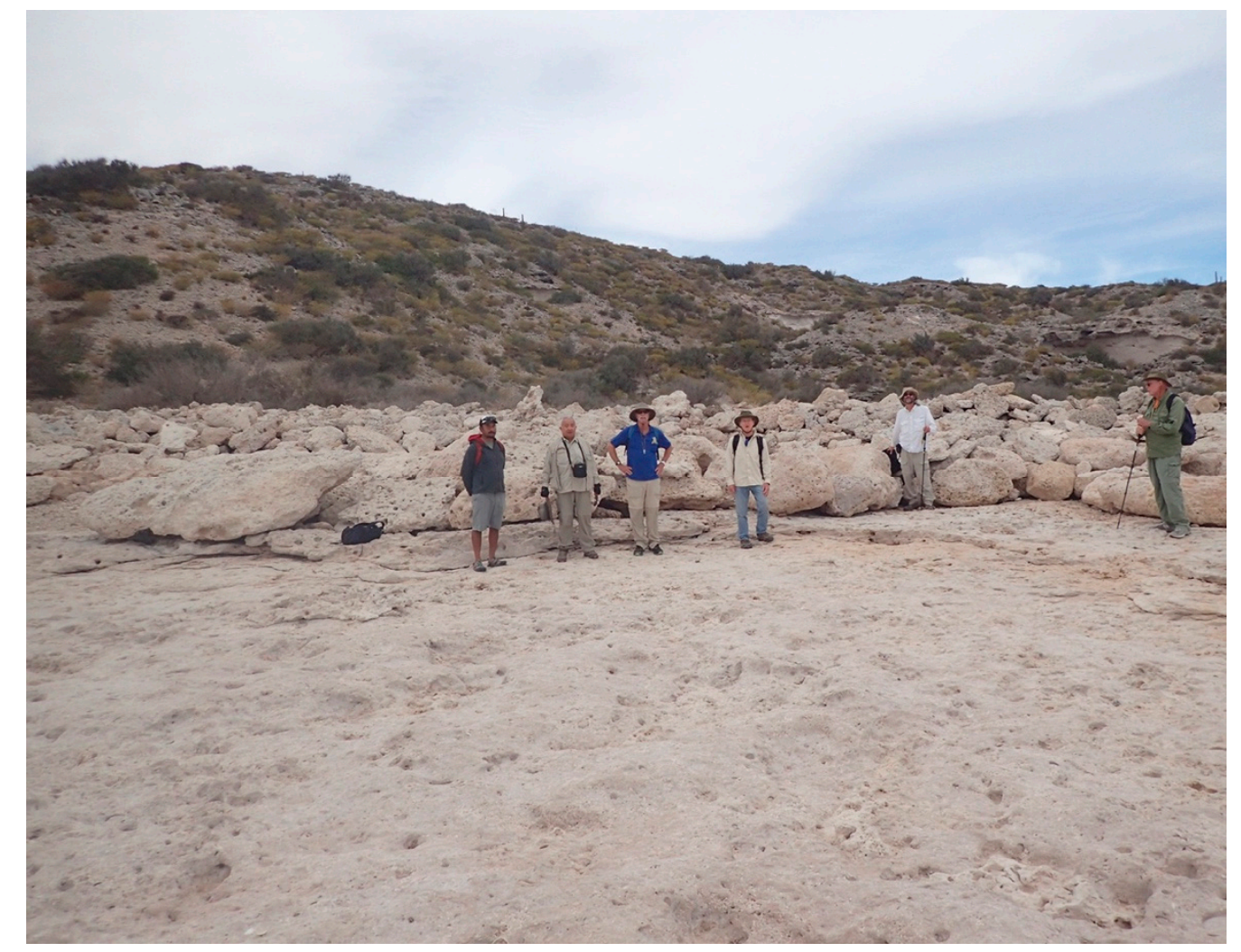

Figure 5. Portion of the coastal boulder deposit (CBD) formed by Pliocene limestone boulders that sit $25 \mathrm{~m}$ back from the outer rim of the 12-m terrace at Arroyo Blanco. 


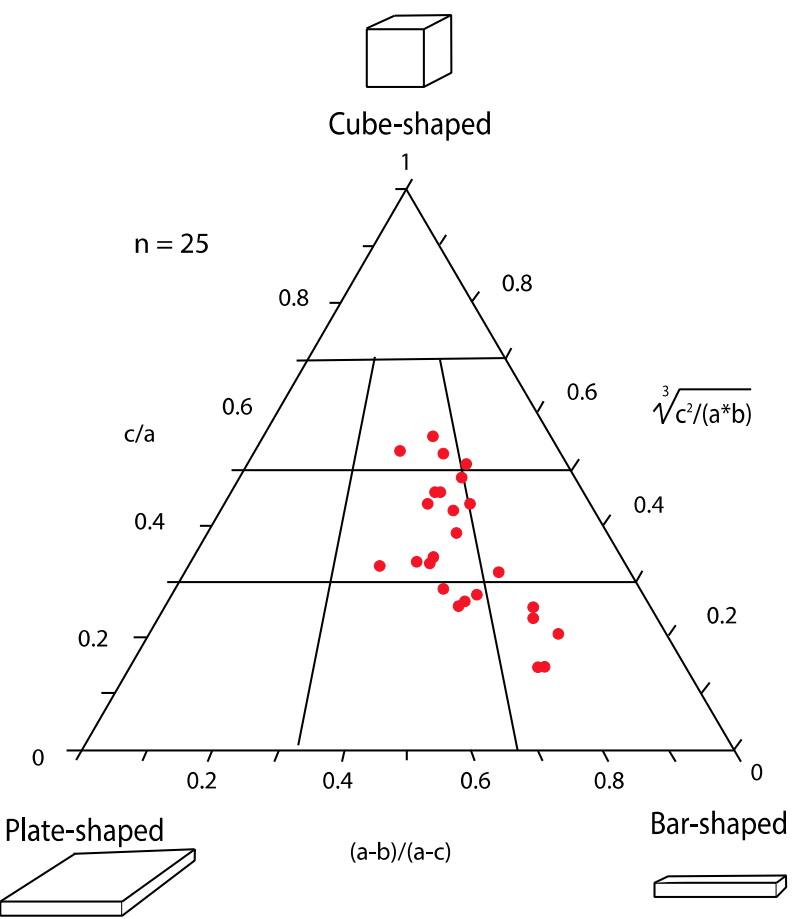

Figure 6. Triangular plot showing the distribution among more cube-shaped, plate-shaped and bar-shaped boulders with sizes and weights recorded in Table 1.

Table 1. Quantification of boulder size, volume and estimated weight from the chaotic storm deposit on the 12-m terrace at Arroyo Blanco, Isla del Carmen. The laboratory result for density at $1.86 \mathrm{gm} / \mathrm{cm}^{3}$ is applied uniformly to all samples in this table. Calculation of wave height is based on results using the formula given by Nott [17].

\begin{tabular}{|c|c|c|c|c|c|c|c|}
\hline Rank & $\begin{array}{l}\text { Long Axis } \\
\text { (cm) }\end{array}$ & $\begin{array}{l}\text { Intermediate Axis } \\
(\mathrm{cm})\end{array}$ & $\begin{array}{l}\text { Short Axis } \\
\text { (cm) }\end{array}$ & $\begin{array}{c}\text { Volume } \\
\left(\mathrm{cm}^{3}\right)\end{array}$ & $\begin{array}{c}\text { Adjust. to } \\
70 \%\end{array}$ & $\begin{array}{c}\text { Weight } \\
\text { (kg) }\end{array}$ & $\begin{array}{c}\text { Wave Height } \\
\text { (m) }\end{array}$ \\
\hline 1 & 182 & 80 & 50 & 728,000 & 509,600 & 948 & 8.4 \\
\hline 2 & 175 & 57 & 60 & 598,500 & 418,950 & 779 & 8.1 \\
\hline 3 & 164 & 87 & 27 & 385,236 & 269,665 & 502 & 7.6 \\
\hline 4 & 153 & 86 & 45 & 592,110 & 414,477 & 771 & 7.1 \\
\hline 5 & 150 & 67 & 46 & 462,300 & 323,610 & 602 & 6.9 \\
\hline 6 & 140 & 60 & 49 & 411,600 & 288,120 & 536 & 6.5 \\
\hline 7 & 117 & 107 & 26 & 325,494 & 227,849 & 424 & 5.4 \\
\hline 8 & 114 & 54 & 32 & 196,992 & 137,894 & 256 & 5.3 \\
\hline 9 & 111 & 74 & 52 & 427,128 & 298,900 & 556 & 5.1 \\
\hline 10 & 106 & 50 & 37 & 196,100 & 137,270 & 255 & 4.9 \\
\hline 11 & 105 & 80 & 35 & 294,000 & 205,800 & 383 & 4.9 \\
\hline 12 & 95 & 75 & 54 & 384,750 & 269,325 & 501 & 4.4 \\
\hline 13 & 90 & 60 & 36 & 194,400 & 136,080 & 253 & 4.2 \\
\hline 14 & 84 & 43 & 14 & 50,568 & 35,398 & 66 & 3.9 \\
\hline 15 & 72 & 45 & 39 & 126,360 & 88,452 & 165 & 3.3 \\
\hline 16 & 70 & 48 & 33 & 110,880 & 77,616 & 144 & 3.2 \\
\hline 17 & 67 & 33 & 24 & 53,064 & 37,149 & 69 & 3.1 \\
\hline 18 & 63 & 50 & 16 & 50,400 & 35,280 & 66 & 2.9 \\
\hline 19 & 59 & 42 & 26 & 64,428 & 45,100 & 84 & 2.7 \\
\hline 20 & 56 & 47 & 15 & 39,480 & 27,636 & 51 & 2.6 \\
\hline 21 & 58 & 52 & 30 & 90,480 & 63,336 & 118 & 2.7 \\
\hline 22 & 52 & 42 & 28 & 61,152 & 42,806 & 80 & 2.4 \\
\hline 23 & 50 & 43 & 25 & 53,750 & 37,625 & 70 & 2.3 \\
\hline 24 & 42 & 26 & 19 & 20,748 & 14,524 & 27 & 1.9 \\
\hline 25 & 40 & 33 & 18 & 23,760 & 16,632 & 31 & 1.9 \\
\hline Average & 96.36 & 57.88 & 33.44 & 236,797 & 165,758 & 308 & 4.3 \\
\hline
\end{tabular}

\subsection{Hydrodynamics}

The hydrodynamic energy necessary to form a coastal boulder deposit (CBD) with heavy blocks either tilted upright from the outer terrace rim at Arroyo Blanco on Isla del Carmen or carried landward 
by as much as $25 \mathrm{~m}$ requires wave heights calculated using Nott's equations from the Methods section. Considering the degree to which most of the boulders have been rounded, a common submerged boulder is a plausible scenario prior to transport by large waves [17]. Prior to this stage, however, blocks would need to be lifted from joint-bound strata. The storm wave required to tip upright the block shown in Figure 3 may have had a wave height of $11.5 \mathrm{~m}$ on impact, according to the formula applied [17]. The storm wave required to tip upright the larger block shown in Figure 4 may have had a wave height close to $14 \mathrm{~m}$ on impact, according to the formula applied [17]. Table 1 lists the wave heights calculated for the 25 individual blocks tested. The maximum wave height determined for the largest block in this sample is $8.4 \mathrm{~m}$, and the minimum needed to move the smallest block is 1.9 . The average wave height for the entire sample was found to be $4.3 \mathrm{~m}$.

\section{Discussion}

All available evidence points to intense storms of hurricane strength as the physical agency most capable of causing sufficient wave energy to dislocate large blocks of limestone from near the top of a 12-m sea cliff through hydraulic wedging along vulnerable bedding planes and vertical joints, to flip upright or overturn them and to transport the smaller blocks inland over a distance of $25 \mathrm{~m}$ across the surface of a marine terrace. Issues regarding the age of the hurricane deposits on Isla del Carmen, their specificity to limestone or other sedimentary-rock formations in the wider Gulf of California and comparisons with major storm deposits elsewhere around world are topics that require additional discussion.

\subsection{Age Relationships}

The precise age of the Carmen hurricane deposit is difficult to pin down. While the limestone blocks are derived from Pliocene strata, it is clear that mobilization first took place after the erosion of a wave-cut platform following the last interglacial episode around 125,000 years ago [18]. Borings by pholad bivalves are preserved several places directly into the surface of the limestone terrace. The fact that some loose limestone blocks also exhibit the borings turned sideways and upside-down indicates that the blocks post-date biological occupation of the wave-cut platform. However, it cannot be excluded that some or all of the action occurred during the interval of time that the terrace was undergoing tectonic uplift. Older, more elevated terraces at Arroyo Blanco that date farther back in the Pleistocene lack comparable storm deposits. It cannot be proven with certainty, but the extreme rough edges of many limestone boulders suggest that the storm deposits are largely Holocene in age. On the other hand, the only sure way to show that extreme storms still impact the 12-m terrace is to tag some of the blocks and find out if they are shifted in position after the next big hurricane.

\subsection{Storm Deposits Elsewhere in the Gulf of California}

Overall, rocky shores in the Gulf of California account for $3000 \mathrm{~km}$ of the composite coastline, or nearly half of all gulf shores and islands, therein, based on a comprehensive survey by satellite imagery [18]. However, the lithological breakdown of rocky shores throughout the full gulf region is dominated by igneous and volcanic cliff lines that account for $37 \%$ of the whole, whereas limestone cliffs account for only $7.5 \%$ in total. Limestone exposed in sea cliffs is especially vulnerable to disturbance by storm waves on account of its natural bedding and a proclivity to vertical jointing. To date, no other limestone rocky shores in the Gulf of California have been examined in any detail from the viewpoint of dislocated storm deposits. The rock type most commonly represented on rocky shores in the Gulf of California is andesite (24\%), but the behavior of this igneous rock in sea cliffs under vigorous wave attack has not been considered. Clearly, there exist many more places around the Gulf of California to pursue this line of investigation.

It is worthy of note that Isla del Carmen provides an effective shield against potential hurricane damage to the towns of Loreto and Nopoló on the adjacent peninsular mainland (Figure 1a, Locality 2). Hurricanes tend to be less numerous and destructive farther to the north, but Isla Angel de la Guarda 
provides a similar offshore shield against direct assault on the town of Bahía de los Angeles in the Upper Gulf of California (Figure 1a, Locality 3). The south and east shores of that particular island denote places of interest where hurricane deposits might be found.

\subsection{Big Storm Deposits Elsewhere in the World}

Recent literature has come to focus on unusual localities where very large rocks are found loose from parent strata and far out of place at higher elevations along the sea coast. Aside from tsunami deposits, which have distinct characteristics among which is extreme mixing of size clasts that range from fine sediment (including soil clumps) to mega-boulders of enormous size [19], supper storms dating from the last interglacial epoch are increasingly called upon to explain the repositioning of mega-boulders on limestone islands such as the Bahamas and Bermuda [20-22]. Moreover, contemporary processes around the Aran Islands of Ireland are the subject of extremely detailed studies undertaken independently by Cox et al. [23] and more recently by Erdmann et al. [24]. The Irish examples bear a closer comparison to the storm deposits from Isla del Carmen, because they entail the dislocation of enormous boulders weighing as much as 50 metric tons from the tops of limestone sea cliffs with as much as $70 \mathrm{~m}$ of vertical profile and the removal of those boulders to inland ridges set back from the seaward front of the cliff line. Major Atlantic storms appear to be the favored agency for the development of these deposits, although hurricane-force storms have not come under consideration until recently with the advent of Hurricane Ophelia, which battered the west coast of Ireland in mid-October 2017. The foresight of ongoing field studies in the Aran Islands is that mega-boulders have been tagged in order to track movements from one year to another. Verification of such movements constitutes the principal argument against the hypothesis that Atlantic tsunamis played a role in the formation of the Irish boulder fields. A similar tagging program would be instrumental in ongoing studies of the Isla del Carmen boulder field on the island's 12-m terrace

\section{Conclusions}

Hurricanes are super storms with the power to modify rocky shorelines through extreme coastal erosion. They also are prone to deliver high amounts of precipitation to inland areas as they pass over the coast. Severe flooding was the main after-effect of historical hurricanes that crossed into the Lower Gulf of California in western Mexico, where damage to infrastructure in population centers like Cabo San Lucas and La Paz occurred with some loss of life. Prior to this study, the main observed effect of hurricanes striking zones such as the unpopulated Isla Cerralvo (Figure 1a, Locality 1) was the episodic progradation of tide-water deltas with sand and cobbles swept down to the sea through normally dry arroyos. This scenario has been used to model the development of mega-delta systems that formed as extensive sandstone and conglomerate formations during the Pliocene Warm Period. However, the present study provides the first evidence that major hurricanes, most likely Holocene in age, impacted and significantly eroded rocky shores along the Gulf coast of the Baja California peninsula.

- The uplifted 12-m marine terrace on the east side of Isla del Carmen is formed by limestone strata deposited during the Pliocene Epoch, the upper part of which is notably eroded where large slabs were peeled back and left in an upright positon.

- The largest of the upright slabs is calculated to weigh between 5.8 and 28 metric tons based on a sample rock density of 1.86 .

- Twenty-five samples studied from the main CBD set back $25 \mathrm{~m}$ from the outer terrace have an average estimated weight of more than $300 \mathrm{~kg}$. The average wave height necessary to move those boulders is calculated as having been $4.3 \mathrm{~m}$.

- No other CBDs occur on the older marine terraces above the 12-m level on Isla del Carmen, and many of the transported boulders from the 12-m terrace include borings by marine bivalves that were active when that surface was being cut at sea level. A precise date is difficult to 
determine, but a Holocene age is more likely based on the roughness of the broken blocks, suggesting that storm impact occurred after tectonic uplift was well underway.

Discovery of the Arroyo Blanco storm deposit on Isla del Carmen opens a new line of enquiry for research in the Gulf of California. Other rocky shorelines formed by various rock types, including limestone and igneous rocks, are certain to come under closer scrutiny.

Author Contributions: M.E.J. and J.L.-V. co-led a field excursion to Baja California Sur (México), during which data were collected on mega-boulder size on Isla del Carmen in the Gulf of California. M.E.J. took charge of field photography and selected a sample for later laboratory determination of rock density. J.L.-V. organized the data summarized in Table 1. R.G.-F. was responsible for working out the mathematics related to storm hydrodynamics.

Funding: This research received no external funding.

Acknowledgments: Members and friends of the San Diego Geologists' Association accompanied the senior authors on a field excursion to Isla del Carmen in February 2018 and enthusiastically contributed to spirited discussions regarding the origin of the deposits on the 12-m terrace. Participants included: Greg Cranham, Mick Hager, Tom Lamb, Diana Lindsay, Lowell Lindsay, Monte Marshall, Diane Murbach, Monte Murbach, Jimmy Smith and Judy Smith. Thanks are due to Ivette Granados in Loreto for her help with logistics for the trip and her assistance in recording data on Isla del Carmen. MEJ is grateful to Jay Racela (Environmental Lab, Williams College) for help with the experimental calculation of density for the limestone sample from Arroyo Blanco. Trevor Murphy (Instructional Technology Specialist at Williams College) helped to fit the manuscript to the templet required by the journal. Comments by anonymous reviews helped to improve earlier drafts of the paper.

Conflicts of Interest: The authors declare no conflict of interest.

\section{References}

1. Trenberth, K.E.; Cheng, L.; Jacobs, P.; Zhang, Y. Hurricane Harvey links to ocean heat content and climate change adaptation. Earth Future 2018. [CrossRef]

2. Mei, W.; Xie, S.-P.; Primeau, F.; McWilliams, J.C.; Pasquero, C. Northwest Pacific typhoon intensity controlled by changes in ocean temperatures. Sci. Adv. 2015, 1, e1500014. [CrossRef] [PubMed]

3. Mei, W.; Xie, S.-P. Intensification of landfalling typhoons over the northwest Pacific since late 1970s. Nat. Geosci. 2016, 9, 753-757. [CrossRef]

4. Oliver, E.C.J.; Donat, M.G.; Burrows, M.T.; Moore, P.J.; Smale, D.A.; Alexander, L.V.; Benthuysen, J.A.; Fend, M.; Gupta, A.S.; Hobday, A.J.; et al. Longer and more frequent marine heatwaves over the century. Nat. Commun. 2018, 9, 1324. [CrossRef] [PubMed]

5. Wara, M.W.; Ravelo, A.C.; Delaney, M.L. Permanent El Niño-loke conditions during the Pliocene Warm Period. Science 2005, 309, 758-761. [CrossRef] [PubMed]

6. Brierley, C.M.; Fedorov, A.V.; Liu, Z.; Herbert, T.D.; Lawrence, K.T.; LaRiviere, J.P. Greatly expanded tropical warm pool and weakened Hadley circulation in the early Pliocene. Science 2009, 323, 1714-1718. [CrossRef] [PubMed]

7. Johnson, M.E.; Ledesma-Vázquez, J.; Backus, D.H. Tectonic decapitation of a Pliocene mega-delta on Isla del Carmen in the Gulf of California (Mexico): And a river ran through it. J. Geol. 2016, 124, 55-74. [CrossRef]

8. Johnson, M.E.; Backus, D.H.; Ledesma-Vázquez, J. Growth of the Ballena fan delta on the Gulf of California (Mexico) at the close of the Pliocene Warm Period. Facies 2017, 63, 14. [CrossRef]

9. Ledesma-Vázquez, J.; Johnson, M.E.; Gonzalez-Yajimovich, O.; Santamaría-del-Angel, E. Gulf of California geography, geological origins, oceanography, and sedimentation patterns. In Atlas of Coastal Ecosystems in the Western Gulf of California; Johnson, M.E., Ledesma-Vázquez, J., Eds.; University Arizona Press: Tucson, Arizona, 2009; pp. 1-10. ISBN 978-0-8165-2530-0.

10. Romero-Vadillo, E.; Zytsev, O.; Morales-Pérez, R. Tropical cyclone statistics in the northeastern Pacific. Atmósperfera 2007, 20, 197-213.

11. Rebman, J.P.; Roberts, N.C. Baja California Plant Field Guide, 3rd ed.; Sunbelt Publications: San Diego, CA, USA, 2012; ISBN 978-0-916251-18-5.

12. Backus, D.H.; Johnson, M.E.; Riosmena-Rodríguez, R. Distribution, sediment source, and coastal erosion of fan-delta systems on Isla Cerralvo (lower Gulf of California, Mexico). J. Coast. Res. 2012, 28, 210-224. [CrossRef] 
13. Kozlowski, J.; Johnson, M.E.; Ledesma-Vázquez, J.; Birgel, D.; Peckmann, J.; Schleper, C. Microbial diversity of a closed salt lagoon in the Puertecitos area, Upper Gulf of California. Cienc. Mar. 2018, 44, 71-90. [CrossRef]

14. Avila, L. The 2015 Eastern North Pacific Hurricane Season: A very active year. Weatherwise 2016, 69, 36-42. [CrossRef]

15. Eros, J.M.; Johnson, M.E.; Backus, D.H. Rocky shores and development of the Pliocene-Pleistocene Arroyo Blanco Basin on Isla Carmen in the Gulf of California, Mexico. Can. J. Earth Sci. 2005, 43, 1149-1164. [CrossRef]

16. Sneed, E.D.; Folk, R.L. Pebbles in the lower Colorado River Texas: A study in particle morphogenesis. J. Geol. 1958, 66, 114-150. [CrossRef]

17. Nott, J.F. Waves, coastal boulder deposits and the importance of the pre-transport setting. Earth Planet. Sci. Lett. 2003, 210, 269-276. [CrossRef]

18. Ortlieb, L. Quaternary vertical movements along the coasts of Baja California and Sonora. In The Gulf and Peninsular Provinces of the Californias; Dauphin, J.P., Simoneit, B.R.T., Eds.; American Association of Petroleum Geologists: Tulsa, OK, USA; pp. 447-580.

19. Backus, D.H.; Johnson, M.E.; Ledesma-Vazquez, J. Peninsular and island rocky shoresin the Gulf of California. In Atlas of Coastal Ecosystems in the Western Gulf of California; Johnson, M.E., Ledesma-Vazquez, J., Eds.; University Arizona Press: Tucson, Arizona, 2009; pp. 11-27. ISBN 978-0-8165-2530-0.

20. Ramalho, R.S.; Winckler, G.; Madeira, J.; Helffrich, G.R.; Hippólito, A.; Quartau, R.; Adena, K.; Schaefer, J.M. Haxard otential of volcanic flank collapses raised by new megatsunami evidence. Sci. Adv. 2015, 1, e1500456. [CrossRef] [PubMed]

21. Hearty, P.J.; Tormey, B.R. Sea-level change and superstorms; geologic evidence from the last interglacial (MIS 5e) in the Bahamas and Bermuda offers ominous prospects for a warming Earth. Mar. Geol. 2017, 390, 347-365. [CrossRef]

22. Rovere, A.; Casella, E.; Harris, D.L.; Lorscheid, T.; Nandasena, N.A.K.; Dyer, B.; Sandstrom, M.R.; Stocchi, P.; D'Andfrea, W.J.; Raymo, M.E. Giant boulders and last interglacial storm intensity in the North Atlantic. Proc. Natl. Acad. Sci. USA 2017, 114, 12144-12149. [CrossRef] [PubMed]

23. Cox, R.; Zentner, D.B.; Kirchner, B.J.; Cook, M.S. Boulder ridges on the Aran Islands (Ireland): Recent movements caused by storm waves, not tsunamis. J. Geol. 2012, 120, 249-272. [CrossRef]

24. Erdmann, W.; Scheffers, A.M.; Kelletat, D.H. Holocene coastal sedimentation in a rocky environment: Geomorphological evidence from the Aran Islands and Galway Bay (Western Ireland). J. Coast. Res. 2018, 34, 772-792. [CrossRef]

(C) 2018 by the authors. Licensee MDPI, Basel, Switzerland. This article is an open access article distributed under the terms and conditions of the Creative Commons Attribution (CC BY) license (http:/ / creativecommons.org/licenses/by/4.0/). 